\title{
Study on the Influencing Factors and Countermeasures of Supply and Demand Balance in Real Estate Market in Dazhou
}

\author{
Xiaomei Pu', Lin Tian², Aili Pu ${ }^{3}$ \\ ${ }^{1}$ Research Center of Sichuan Old Revolutionary Areas Development, Sichuan University of Arts and Science, Dazhou, China \\ ${ }^{2}$ School of Foreign Languages, Sichuan University of Arts and Science, Dazhou, China \\ ${ }^{3}$ Chengdu Neusoft University, Chengdu, China \\ Email: 47872614@qq.com
}

How to cite this paper: Pu, X.M., Tian, L. and Pu, A.L. (2018) Study on the Influencing Factors and Countermeasures of Supply and Demand Balance in Real Estate Market in Dazhou. Open Journal of Business and Management, 6, 551-557. https://doi.org/10.4236/ojbm.2018.63041

Received: April 28, 2018

Accepted: May 19, 2018

Published: May 22, 2018

Copyright $\odot 2018$ by authors and Scientific Research Publishing Inc. This work is licensed under the Creative Commons Attribution International License (CC BY 4.0).

http://creativecommons.org/licenses/by/4.0/

\begin{abstract}
Taking supply and demand of real estate market in Dazhou as an example, this paper obtains the main factors affecting the supply of real estate market by interviews and consulting relevant information. Through questionnaire and further analysis, the main factors affecting the demand of real estate market are brought forward. Countermeasures are then proposed to achieve the balance between supply and demand as well as stable and healthy development of Dazhou's real estate market.
\end{abstract}

\section{Keywords}

Dazhou, Real Estate, Influencing Factors, Countermeasures

\section{Introduction}

As the "East Gate" through which Sichuan opens itself to the outside world, Dazhou serves as a famous old revolutionary area. In recent years, the real estate industry in Dazhou has achieved certain development and gradually become a pillar industry for the city's economic development. According to the statistics of early 2018, the real estate development investment in Dazhou in 2017 was 11.364 billion yuan, an increase of $21.8 \%$. The construction area of commercial houses was $9,988,500$ square meters, an increase of $4.1 \%$ over the previous year. The sold area of commercial houses was 4,063,200 square meters, an increase of $58.1 \%$. The to-be-sold area of commercial houses was 850,100 square meters, a decrease of $6.8 \%$, and the destocking effect was obvious. Meanwhile, such problems remain acute as the excessive growth of house prices, the excessively high 
price-to-income ratio, and the mismatch between supply and demand. These problems not only affect the sustainable and healthy development of the real estate market, but also influence the entire socio-economic development. In this context, it is particularly vital to research on the factors that influence the supply and demand of the real estate market.

\section{Analysis on the Influencing Factors of Supply and Demand in Dazhou's Real Estate Market}

\subsection{Analysis on the Influencing Factors of Supply}

Through interviews with real estate developers and access to relevant information, we have learnt that the supply of real estate in Dazhou mainly depends on the price of real estate, the price of real estate production factors, the supply of affordable housing, and the future expectations of developers, etc. [1].

Firstly, the price of real estate. Real estate prices are one of the important factors that affect real estate supply. According to the principle of supply, the higher the price of a commodity is, the greater the output provided by producers will be, and the lower the price of the commodity is, the smaller the output will be. According to on-site survey of Dazhou, the average transaction price of residential properties in Dazhou's downtown area was RMB 4912.17 per square meter in 2014. The same year, 12,110 new houses were built, covering an area of 1.0384 million square meters. In 2015, the average transaction price dropped to RMB 4792.11 per square meter, a year-on-year decrease of $2.44 \%$. The newly launched residential houses totaled 11,036 with a total area of 981,600 square meters, respectively decreasing 1074 houses and 56,800 square meters. This further proves that the real estate supply is directly proportional to the real estate price.

Secondly, the price of real estate production factors. Real estate supply is inversely proportional to the price of real estate production factors. The prices of real estate production factors mainly include land, construction materials, labor costs, capital prices, and government management costs. Land cost is an important part of real estate development costs. According to the survey, the average price of residential land in 300 cities nationwide in 2015 was RMB 2223 per square meter, an increase of $24 \%$ year-on-year, which greatly increased the cost of real estate development. Building materials and labor costs are also important for the real estate commodity development costs. In recent years, with the continuous development of the real estate industry, the prices of construction materials and labor costs have also continued to rise, which has led to a continuous increase in the cost of housing construction. The capital price is also a significant component of real estate development costs. It refers to the financing costs of developers in order to develop real estate, including loan costs (interest and related expenses), the cost of issuing bonds (interest and related expenses), the cost of capital stock (profit sharing) and the cost of credit financing, etc. Besides, the government's management cost also has to be paid by real estate developers, which mainly includes deed tax, business tax, urban maintenance and construc- 
tion tax, educational surcharges, urban land use tax, land value-added tax and corporate income tax, etc.

Thirdly, the supply of affordable housing. Affordable housing is a kind of quasi-public goods, which is a realistic choice to ensure social fairness and solve housing problems for low-and-middle-income families. Whether the supply of affordable housing affects the supply of commercial housing mainly depends on the construction scale and the source of affordable housing. If the scale of affordable housing is not large enough, it will have little impact on the supply of commercial housing. If affordable housing is guaranteed through the purchase of commercial housing, it will further promote the supply of commercial housing. If large-scaled affordable housing is built by the State itself, it will have a crowding effect on the supply of commercial housing.

Fourthly, the future expectations of real estate developers. The developers' expectations for the future are crucial, for real estate features long development cycles, large investment and high risks. If real estate developers are optimistic about the future, they will increase the supply of real estate. If not, they will reduce the supply. In recent years, confronted with economic downward pressure and high inventory, the real estate developers lose their confidence in investment, which leads to the failure of many land auctions. However, the investment confidence of real estate developers has rebounded with a series of government rescue policies in 2015 .

\subsection{Analysis on the Influencing Factors of Demand}

According to the questionnaire, the main influencing factors affecting real estate demand are real estate prices, consumer's income, affordable housing construction, consumer preferences, and consumer's expectations for real estate prices.

Firstly, the price of the real estate. In general, the higher the price of a commodity is, the less the demand for the commodity will be, and the lower the price is, the greater the demand will be. Since real estate product has the specificity of rigid demand, investment demand, and speculative demand [2], its price can also exert different impacts on real estate demand. Sometimes there may even be a phenomenon of the Giffen effect, that is, the higher the price is, the larger the sales volume will be, and the lower the price is, the lower sales volume will be. This phenomenon will lead to high real estate prices, further stimulating the real estate bubble.

Secondly, the income of consumers. When consumer's income increases, their demand for most commodities will rise. On the contrary, when consumer's income decreases, their demand will drop. It is also true for real estate. Although the economic development of our country has slowed down and entered a new normal in recent years, Chinese people's income maintains rapid growth. In 2016, China's per capita disposable income stood at 23,821 yuan, $62.6 \%$ upover 2010. Therefore, residential real estate still has a large market potential.

Thirdly, the construction of affordable housing. There is an alternative relationship between affordable housing and commercial housing. If affordable hous- 
ing is easily applied with convenient procedures and lower price than commercial housing, consumers will have greater demand for affordable housing and less demand for commercial housing, and vice versa [3].

Fourthly, the preferences of consumers. When consumers' preference for a certain product increases, the demand for the product will increase, and vice versa. The survey shows that consumer preferences have a strong relationship with consumers' age and occupation, etc. (see Table 1 and Table 2). For consumers of different ages, they have different preference. Those aged 18 - 25 have the greatest preference for transport convenience, those aged 25 - 40 preferring peripheral education facilities and those above 40 preferring housing prices. For consumers of different occupations, although their preferences vary, they all have the greatest preference for housing prices.

Table 1. Consumer preferences at different ages.

\begin{tabular}{|c|c|c|c|c|}
\hline $\begin{array}{c}\text { Age } \\
\text { preference }\end{array}$ & Age 18 - 25 & Age $25-40$ & Age $40-50$ & Age above 50 \\
\hline Preference One & $\begin{array}{l}\text { Convenient } \\
\text { transportation }\end{array}$ & Educational facilities & Housing price & Housing price \\
\hline Preference Two & $\begin{array}{l}\text { Consumption and } \\
\text { recreational facilities }\end{array}$ & Housing price & $\begin{array}{l}\text { Community } \\
\text { greening }\end{array}$ & $\begin{array}{l}\text { Community } \\
\text { greening }\end{array}$ \\
\hline Preference Three & Housing price & $\begin{array}{c}\text { Convenient } \\
\text { transportation }\end{array}$ & $\begin{array}{l}\text { Convenient } \\
\text { transportation }\end{array}$ & House type \\
\hline Preference Four & House type & $\begin{array}{l}\text { Community } \\
\text { greening }\end{array}$ & $\begin{array}{l}\text { Construction } \\
\text { quality }\end{array}$ & Medical support \\
\hline Preference Five & $\begin{array}{c}\text { Property } \\
\text { management }\end{array}$ & Construction quality & House type & $\begin{array}{l}\text { Construction } \\
\text { quality }\end{array}$ \\
\hline
\end{tabular}

(Source: Questionnaire).

Table 2. Preferences of consumers with different occupations.

\begin{tabular}{|c|c|c|c|c|c|}
\hline $\begin{array}{l}\text { Occupation } \\
\text { preference }\end{array}$ & $\begin{array}{l}\text { Personnel of } \\
\text { government } \\
\text { agencies or } \\
\text { institutions }\end{array}$ & Teacher & $\begin{array}{c}\text { Bank or } \\
\text { financial } \\
\text { practitioners }\end{array}$ & $\begin{array}{l}\text { Private business } \\
\text { owners, individual } \\
\text { business owners }\end{array}$ & $\begin{array}{l}\text { Employee of } \\
\text { manufacturing or } \\
\text { retailor industry }\end{array}$ \\
\hline $\begin{array}{l}\text { Preference } \\
\text { One }\end{array}$ & Housing price & Housing price & Housing price & Housing price & Housing price \\
\hline $\begin{array}{c}\text { Preference } \\
\text { Two }\end{array}$ & $\begin{array}{l}\text { Community } \\
\text { greening }\end{array}$ & $\begin{array}{l}\text { Community } \\
\text { greening }\end{array}$ & $\begin{array}{l}\text { Community } \\
\text { greening }\end{array}$ & $\begin{array}{l}\text { Community } \\
\text { greening }\end{array}$ & House type \\
\hline $\begin{array}{l}\text { Preference } \\
\text { Three }\end{array}$ & $\begin{array}{l}\text { Convenient } \\
\text { transportation }\end{array}$ & House type & $\begin{array}{l}\text { Convenient } \\
\text { transportation }\end{array}$ & $\begin{array}{l}\text { Convenient } \\
\text { transportation }\end{array}$ & $\begin{array}{l}\text { Convenient } \\
\text { transportation }\end{array}$ \\
\hline $\begin{array}{l}\text { Preference } \\
\quad \text { Four }\end{array}$ & House type & $\begin{array}{c}\text { Convenient } \\
\text { transportation }\end{array}$ & House type & $\begin{array}{c}\text { Property } \\
\text { management }\end{array}$ & $\begin{array}{l}\text { Consumption and } \\
\text { entertainment } \\
\text { facilities }\end{array}$ \\
\hline $\begin{array}{c}\text { Preference } \\
\text { Five }\end{array}$ & $\begin{array}{c}\text { Property } \\
\text { management }\end{array}$ & $\begin{array}{l}\text { Consumption } \\
\text { and } \\
\text { entertainment } \\
\text { facilities }\end{array}$ & $\begin{array}{l}\text { Consumption } \\
\qquad \text { and } \\
\text { entertainment } \\
\text { facilities }\end{array}$ & House type & $\begin{array}{l}\text { Community } \\
\text { greening }\end{array}$ \\
\hline
\end{tabular}

(Source: Questionnaire). 
Lastly, consumers' expectations for real estate prices. When consumers expect that real estate prices will rise in the next period, the current demand for real estate will increase and vice versa. In 2014, Chinese real estate moved from the "Golden Age" to the "Silver Age". That is, the real estate market is still confronted with the downward pressure even with the support of a series of national stimulus policies. Consumers expect that real estate prices will continue to fall, so most consumers have a wait-and-see attitude toward real estate in 2015.

\section{Countermeasures of Supply and Demand Balance in Dazhou's Real Estate Market}

To achieve the balance between supply and demand in Dazhou's real estate market, we need to discuss from the perspectives of supply side and demand side.

\subsection{Supply Side}

\subsubsection{Building High Quality Housing}

With the improvement of people's living standards, they have higher demand for real estate. Therefore, the developers must fully investigate the real estate market before real estate development and design, thoroughly knowing consumers' preferences and purchasing power. During design and development, the developers should give full consideration to different consumers' demands for housing and their economic power, not only laying emphasis on the utility and beauty of the housing, but also stressing on internal environment and external supporting facilities. Meanwhile, they should select good property companies and build high-quality houses that allow residents to live comfortably and securely.

\subsubsection{Reducing the Cost of Housing Construction}

The cost of housing construction is mainly composed of land costs, material costs, labor costs, capital costs, and government management costs. Land costs have always been an important part of the housing construction costs. Therefore, it is necessary to optimize the land transfer model to control land prices and then control house prices. The second is the cost of construction materials and labor costs. In this regard, enterprises should actively conduct research and development to improve related technologies and materials and reduce the cost of construction materials while ensuring the quality of buildings. At the same time, efficient management methods should be introduced. Then, in terms of capital costs, banks should cut interest rates to reduce capital costs in areas where house prices and income ratios are excessively high. Lastly, the government should simplify management procedures and cancel unreasonable or overlapping charges to reduce the burden of developers and buyers.

\subsubsection{Increasing the Number of Affordable Housing}

Dazhou has the largest poverty-stricken population in Sichuan province. Therefore, it is necessary to increase affordable housing to solve the housing problem of the local people in Dazhou. In the construction of affordable housing, the fol- 
lowing aspects need to be noted: Firstly, establish a well-defined affordable housing system [4] by providing low-income families with low-rent housing and providing low-and-middle-income people with limited-price commodity housing. Secondly, guarantee the quality of affordable housing by building affordable houses and purchasing commercial houses as affordable ones. Thirdly, improve the access and exit mechanism. Application and approval procedures should be simplified to those residents who meet the requirements of affordable housing. For those residents who have growing income and thus do not meet the requirements, they should no longer enjoy this welfare by returning the affordable houses.

\subsection{Demand Side}

\subsubsection{Improving the Income of Residents}

Residents' income is an important factor affecting the demand of real estate market. Only when residents' income is increased to a certain level will the demand aspiration turn to reality. Therefore, the government needs to further deepen the reform of the income system and improve the proportion of residents' income in the national revenue, finally solving the house purchasing problem for residents, low-and-middle-income families in particular.

\subsubsection{Perfecting Differentiated Credit Policies}

Residents' demand for housing includes rigid demand, improved demand, investment demand and speculative demand. In terms of different types of demand, differentiated credit policies should be implemented. Rigid demand and reasonable improved demand should be supported by implementing lower down payment ratios and loan interest rates, while investment and speculative demand should be suppressed in order to prevent the real estate bubble by raising the down payment ratio and interest rates.

\subsubsection{Guide Residents to Have Reasonable Expectations for Housing}

The asymmetry of real estate information will lead to residents' unreasonable expectations for housing and their blind trend following. Therefore, an information platform should be established to timely release and analyze relevant information. Dazhou currently has two information exchange platforms, Dazhou Real Estate Management Bureau and Dafang Network, to release the real estate-related information in the region, but the information published is flawed and lacks in-depth analysis. In order to solve the problem of real estate information asymmetry in Dazhou and guide residents to have a reasonable expectation for real estate, we should further improve the two information platforms so that homebuyers can objectively analyze their own purchase needs based on the obtained information.

\section{Conclusion}

The real estate industry is an important pillar industry in China, which is closely 
related to the national economy and people's livelihood. In recent years, the real estate industry in Dazhou City and China has problems such as excessive growth of house prices, high price-to-income ratios, and mismatched supply and demand. It is necessary to analyze their causes and propose countermeasures from the perspective of both supply and demand. Besides, the government, enterprises and residents need to work together to address these issues.

\section{Acknowledgements}

This work was sponsored by Research Center for the reform and development of newly built colleges and universities (Project Number: XJXY2016C01).

\section{References}

[1] Gao, H.Y. (2007) Western Economics. China Renmin University Press, Beijing.

[2] Jia, L.F., Liu, J.H. and Zhang, T. (2009) Analysis of the Factors Affecting the Supply and Demand of China's Real Estate Market. China Trading, 7, 187-188.

[3] Lv, P., Qi, R.S. and Li, S. (2014) The Impact of Affordable Housing Construction in the Commercial Housing Market. Business Research, 1, 39-47.

[4] Du, R.Y. (2015) Daqing's Real Estate Supply and Demand Status and Suggestions. Daqing Social Sciences, 2, 75-76. 